\title{
Pelatihan Resiliensi Pada Remaja Panti Asuhan
}

\author{
Resilience Training For Orphanage Adolescent \\ Kimmy Katkar ${ }^{1 *}$, Purwaningtyastuti ${ }^{2}$, Retno Ristiasih Utami ${ }^{3}$ \\ Fakultas Psikologi, Universitas Semarang, Kota Semarang, Indonesia \\ *Penulis Korespondensi \\ kimmy@usm.ac.id, pungkycute14@gmail.com, ririez03@usm.ac.id
}

Riwayat Artikel: Dikirim 27 Agustus 2021; Diterima 4 November 2021; Diterbitkan 30 November 2021

\begin{abstract}
Abstrak
Remaja yang tinggal di panti asuhan hanya akan terpenuhi kebutuhan fisiologisnya saja namun tidak kebutuhan psikologisnya, hal ini disebabkan karena situasi panti asuhan dengan jumlah pengasuh dan anak panti yang tidak seimbang bisa saja menimbulkan suatu permasalahan psikologis. Minimnya bimbingan dari pengasuh secara lebih mendalam bisa menjadi salah satu faktor pemicu remaja di panti asuhan ketika mengalami permasalahan dalam hidupnya akan lebih rentan mengalami stres, tekanan dan depresi. Sehingga membuat individu mudah terpuruk dan sulit bangkit kembali. Metode pelaksanaan dalam kegiatan pengabdian ini dilakukan secara offline dengan diberikan ceramah, studi kasus dan game. Kegiatan dievaluasi dengan menggunakan model pengukuran pretest dan post-test. Berdasarkan hasil analisa dengan menggunakan Paired Sample T-Test didapatkan ada peningkatan sebesar 17,98 dengan skor perbedaan mean pretest 56,95 dan post-test 74,93 . Hal ini menunjukkan adanya peningkatan resiliensi pada remaja yatim piatu setelah diberikan pelatihan. Kegiatan yang sudah dilakukan sangat bermanfaat bagi remaja dengan adanya peningkatan resiliensi dan mendapatkan pengetahuan baru yang mana sebelum adanya kegiatan ini remaja tidak mengetahui makna dan pentingnya individu memiliki resiliensi yang tinggi.
\end{abstract}

Kata kunci: Resiliensi, Remaja

\begin{abstract}
Adolescent who live in orphanages will only have their physiological needs met but not their psychological needs, this is because the condition of the orphanage with the number of caregivers and orphans that are not comparable can cause psychological problems. The lack of guidance from caregivers in more depth can be one of the triggering factors for adolescents who live in orphanages when experiencing problems in their lives to be more susceptible to stress, pressure and depression. This makes it easy for individuals to fall and find it difficult to get back up. The implementation method in this service activity is carried out offline by giving lectures, case studies and games. Activities were evaluated using the pretest and post-test measurement models. Based on the results of the analysis using the Paired Sample T-Test, it was found that there was an increase of 17.98 with a difference in the mean score of pretest 56.95 and post-test 74.93 . This shows an increase in resilience in orphaned adolescents after being given training. The activities that have been carried out are very useful for adolescents by increasing resilience and gaining new knowledge which before this activity teenagers did not know the meaning and importance of individuals having high resilience.
\end{abstract}

Keywords: Youth, Resilience

\section{PENDAHULUAN}

Setiap individu dalam menjalani kehidupan pasti menginginkan sebuah kehidupan yang selalu berjalan dengan baik dan lancar, namun terkadang realita hidup berkata lain dimana dalam menjalani kehidupan tidak selamanya berjalan baik sesuai dengan harapan dan keinginan ada kalanya pada suatu saat individu tersebut berada di posisi bawah. Setiap individu pastinya pernah mengalami suatu masalah dan berakibat akan adanya suatu kegagalan. Pada masa-masa ini tidak jarang terdapat individu yang akan jatuh, terpuruk, muncul sikap pesimis dan sulit untuk bangkit kembali. Salah satunya adalah bagi remaja, dimana 
pada fase remaja bisa dikatakan sebagai fase perubahan. Masa yang penuh gejolak dan tekanan, karena pada fase ini remaja dihadapkan dengan berbagai macam masalah, tantangan, perubahan fisik, sosial, psikologis dan emosi.

Remaja perlu memiliki daya tahan atau yang biasa disebut dengan resiliensi. Kemampuan tersebut tidak bisa didapatkan begitu saja namun butuh proses yang cukup lama, maka dari itu setiap remaja dapat belajar untuk menjadi pribadi yang resilien darimana saja, kapanpun dan dimanapun. Kemampuan resiliensi yang dimiliki tentu sangat bermanfaat sebagai bekal ketika di masa mendatang saat mengalami suatu masalah, remaja akan mampu untuk mengatasinya, bangun dan bangkit dari keterpurukan hingga menjadi seorang pribadi yang mempunyai rasa percaya diri, optimis, mampu berpikir logis dan memiliki rasa tanggung jawab.

Kondisi di panti asuhan sendiri terdapat jumlah yang tidak seimbang dimana jumlah pengasuh yang tidak seimbang dengan jumlah anak asuh yang berada di panti. Situasi semacam ini dapat mendorong munculnya berbagai macam permasalahan psikologis. Remaja di panti asuhan bisa menjadi kurang mendapatkan perhatian, kasih sayang atau pengarahan dari para pengasuh. Sedikitnya bimbingan yang diterima, individu harus mampu menjalani hidupnya sendiri. Hal ini sesuai dengan (Illahi \& Akmal, 2017) yang berpendapat bahwa kehidupan yang dijalani oleh remaja di panti asuhan memiliki beberapa tantangan. Sebagai contoh, jumlah pengasuh yang tidak seimbang dengan jumlah anak asuhnya bisa menjadikan remaja yang tinggal di panti asuhan kurang memperoleh dukungan sosial, moral dan bimbingan. Dimana seharusnya seorang remaja yang masih mengalami perkembangan psikologis lebih membutuhkan keberadaan dan dukungan dari orang tua, namun hal itu tidak bisa di dapatkannya. Sehingga dengan kondisinya seperti itu maka akan mendorong anak panti untuk bisa lebih mandiri.

Masa remaja termasuk salah satu fase yang penting dalam proses perkembangan, oleh karena itu dibutuhkan pendampingan secara intens baik fisik maupun psikologis dari orang tua agar dapat membantu individu saat dihadapkan suatu permasalahan terutama jika masalah tersebut tergolong masalah berat. Namun karena menyandang status yatim piatu saat remaja, maka bisa menimbulkan suatu masalah bagi individu. Oleh karena itu remaja membutuhkan perhatian dan bimbingan secara mendalam agar membantu proses perkembangan remaja dalam menjalani kehidupan. Pengalaman selama berada di panti asuhan akan memengaruhi sikap dan perilaku remaja dalam menjalani kehidupan sehari-hari. Selama berada di panti asuhan kebutuhan fisiologis remaja akan terpenuhi namun tidak kebutuhan psikologisnya, hal ini disebabkan karena kurangnya bimbingan, kasih sayang dan perhatian secara intens pada masingmasing individu. Suseno (2013), menyatakan bahwa remaja yatim piatu dapat terhambat perkembangan pribadinya dengan menunjukkan sikap menutup diri, berperilaku agresif dan memperlihatkan prasaan inferior dan pasif. Emosi remaja yang hidup tanpa orang tua sering bergejolak dan tidak stabil, karena status dirinya yang berbeda dengan teman, orang lain dan orang terdekat lainnya. Remaja yang tinggal di panti asuhan tentu akan mengalami perkembangan psikologis berbeda dengan remaja yang masih memiliki keluarga utuh dan tinggal di rumah. Remaja panti akan lebih rentan terhadap tekanantekanan negatif dan akan mudah terpuruk saat dihadapkan suatu permasalahan yang cukup berat karena kurangnya dukungan psikologis dari orang tua.

Remaja yang tinggal di panti asuhan memiliki perasaan rendah diri, cenderung pasif, kurang peduli, menarik diri, mudah putus asa, cepat merasa takut dan cemas jika dibandingkan dengan remaja yang masih 
memiliki orang tua (Widiasavitri, 2016). Hal ini sesuai dengan hasil wawancara awal dengan pimpinan panti asuhan yang mengemukakan bahwa ada beberapa remaja yang cenderung menutup diri dan pasif sehingga sulit membedakan apakah remaja tersebut sedang mengalami suatu masalah atau tidak. Ketika di dekati oleh pengasuh, terdapat beberapa remaja yang terlihat kurang percaya diri, hal ini disebabkan karena kurang dekatnya hubungan antara pengasuh dengan remaja tersebut. Sehingga individu lebih memilih untuk membatasi dirinya dengan orang lain yang dirasa tidak memiliki kelekatan hubungan.

Selain itu permasalahan yang sering dialami oleh remaja di panti asuhan adalah mempunyai perasaan berbeda dengan remaja lain yang memiliki orang tua. Hal ini bersumber dari faktor utama yaitu kelengkapan sebuah keluarga, yang mana hal ini tidak bisa dirasakan oleh remaja yang tinggal di Panti Asuhan. Karena tidak mempunyai sebuah keluarga yang utuh, seringkali mereka mendapat perlakuan yang berbeda dari lingkungan sosialnya. Situasi seperti ini bisa menjadi faktor pemicu munculnya berbagai macam emosi negatif sehingga tidak mampu beradaptasi dan menjalin interaksi sosial dengan baik di lingkungan sosial.

Menurut (Rojas F., 2015), berpendapat bahwa resiliensi adalah kemampuan menghadapi tantangan, resiliensi akan terlihat ketika seseorang menghadapi pengalaman yang sulit dan tahu bagaimana menghadapi atau beradaptasi dengannya. Situasi yang dialami oleh remaja dalam hal ini adalah situasi di mana tidak semua orang mampu mengatasinya. Oleh sebab itu, resiliensi merupakan suatu proses yang dialami oleh individu bukan suatu sifat yang melekat pada individu. Terdapat beberapa ciri-ciri individu yang resilien menurut (Desmita, 2014) yaitu kesanggupan diri untuk melayani orang lain, menggunakan keterampilan hidup (keterampilan mengambil keputusan dengan baik, tegas, keterampilan mengontrol impuls dan problem solving), sosiabilitas (kemampuan untuk menjadi seorang teman, kemampuan untuk membentuk hubungan-hubungan yang positif), memiliki perasaan humor, lokus kontrol internal, otonomi, memiliki pandangan yang positif terhadap masa depan, fleksibilitas, memiliki kapasitas untuk terus belajar, motivasi diri, kompetensi personal dan memiliki harga diri.

Aspek-aspek yang membentuk resiliensi diantaranya adalah kompetensi personal, standar yang tinggi dan ketekunan, percaya diri, memiliki toleransi terhadap afek negatif dan tangguh dalam menghadapi tekanan, penerimaan positif terhadap perubahan, interaksi sosial dengan baik terhadap orang lain, mampu mengendalikan emosi dan spiritualitas (Connor \& Davidson, 2003). Sedangkan faktor yang memengaruhi resiliensi ada dua yaitu faktor internal dan faktor eksternal. Faktor internal merupakan kemampuan yang berasal dari diri sendiri, sedangkan lingkungan merupakan salah satu faktor eksternal yang dapat memengaruhi resiliensi individu (Herdiani, 2018).

Berdasarkan permasalahan diatas, diperlukan adanya pelatihan tentang strategi untuk meningkatkan resiliensi dengan tujuan para remaja di panti asuhan lebih mampu dan tangguh dalam menghadapi segala permasalahan hidupnya dengan penuh emosi positif, perasaan optimis, sabar dalam menghadapi suatu cobaan dan mampu beradaptasi dengan baik di lingkungan sosialnya tanpa ada emosi negatif atau tekanan-tekanan dalam diri individu.

\section{METODE}

Pelaksanaan program kegiatan pengabdian kepada masyarakat dilaksanakan pada hari Senin tanggal 12 April 2021. Pelatihan ini diikuti oleh 16 remaja di panti asuhan YBMI Semarang. Bapak Didin selaku pemimpin panti asuhan turut serta mendampingi mulai dari awal kegiatan 
sampai selesai. Kegiatan pengabdian berbentuk program pelatihan yaitu berupa pelatihan mengenai bagaimana strategi untuk meningkatkan resiliensi pada masing-masing remaja. Kegiatan pengabdian berlangsung sekali selama 180 menit. Metode yang digunakan untuk menganalisis hasil pelatihan ini adalah metode kuantitatif eksperimen dengan desain pretest dan posttest. Pretest diberikan sebelum pelatihan dan posttest diberikan setelah pelatihan. Teknik pengolahan data dilakukan menggunakan uji beda (T-Test).

Adapun bentuk pelaksanaan pengabdian yaitu sebagai berikut :

a. Ceramah : diberikan sebagai pengantar pelatihan. Dalam sesi ceramah ini dibagi menjadi tiga tahap. Pertama, diberikan ceramah sebagai sarana pemberian informasi terkait dengan gambaran dan makna resiliensi. Ceramah selanjutnya adalah membahas mengenai dampak positif individu yang memiliki tingkat resiliensi tinggi dan dampak negatif individu yang memiliki tingkat resiliensi rendah. Sedangkan ceramah terakhir membahas mengenai bagaimana cara meningkatkan resiliensi yang ada pada masing-masing remaja.

b. Pelatihan : Pelatihan diberikan setelah sesi ceramah, yaitu latihan yang ditunjukkan melalui pemberian tiga game dan analisa kasus secara individu maupun kelompok.

c. Tanya Jawab dan Evaluasi : dilakukan bersama, sebagai penguatan dan saling tukar pengalaman dalam menghadapi sebuah permasalahan dalam kehidupan. Selain itu melalui diskusi dan sharing, sesi ini juga menjadi sesi evaluasi terkait dengan pelaksanaan dan isi materi.

\section{HASIL DAN PEMBAHASAN}

Berdasarkan hasil pretest dan posttest terkait pelatihan resiliensi remaja panti asuhan, diketahui terdapat perbedaan mengenai tingkatan resiliensi remaja dari sebelum dan sesudah diberikan pelatihan.

Tabel 1 :

Hasil Pre-Test dan Post-Test

\begin{tabular}{lccc}
\hline & Kelompok & N & Mean \\
& & & \\
\hline Resiliensi & Pretest & 16 & 56,95 \\
& & & \\
\hline & Posttest & 16 & 74.93
\end{tabular}

Hasil analisis data dengan Paired Sample T-Tes menunjukkan adanya peningkatan resiliensi pada remaja yatim piatu dengan skor sebesar 17,98. Nilai pretest yang semula 56,95 menjadi 74,93 pada perhitungan posttest, yang menunjukkan adanya peningkatan resiliensi pada remaja yatim piatu dari sebelum dan sesudah diberikan pelatihan.

Grafik 1:

Pre-test-Post-test

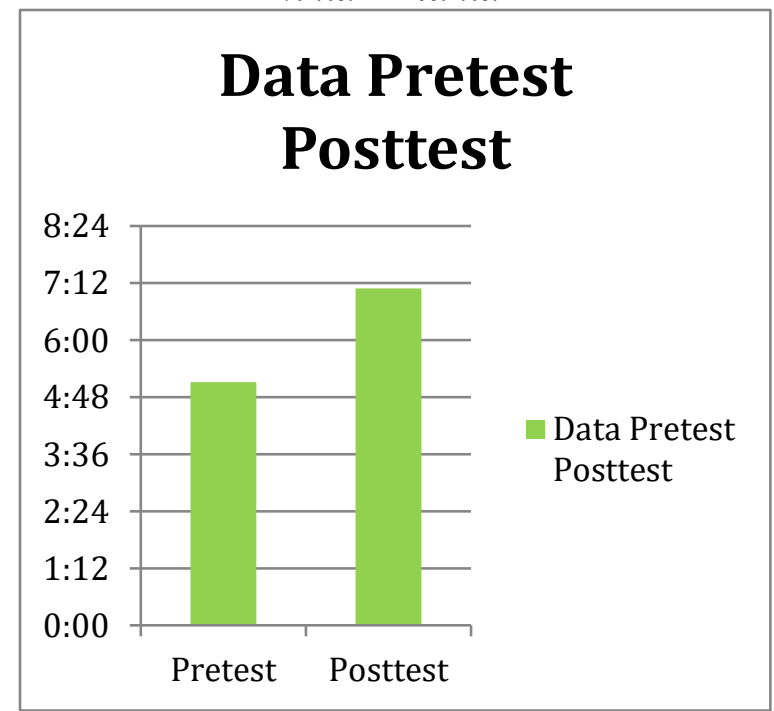


Gambar 1:

Dokumentasi Kegiatan
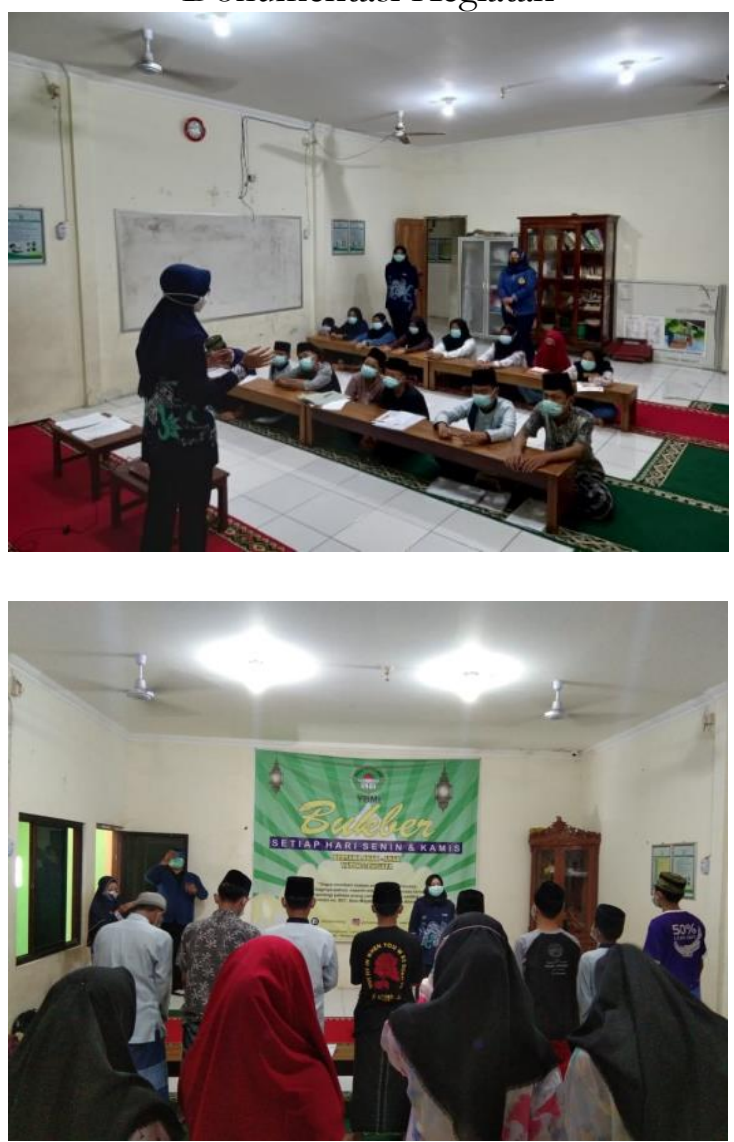

Sumber: Dokumentasi Pribadi

Banyak faktor pemicu mundulnya stresor pada remaja, salah satunya adalah faktor keutuhan keluarga. Ketika remaja memiliki keluarga yang tidak utuh maka individu kurang mendapat perhatian dan dukungan sosial dari keluarganya. Hal ini bisa saja menyebabkan keterpurukan remaja dalam menghadapi suatu masalah karena tidak mampu untuk mengatasi masalah tersebut. Dari sini yang menyebabkan rendahnya tingkat resiliensi pada individu (Purwanti \& Aulia, 2017). Sedikitnya perhatian dan bimbingan yang diterima menjadi salah satu faktor pendorong remaja panti asuhan lebih rentan mengalami tekanan emosi negatif dibandingkan dengan remaja yang tinggal di rumah serta memiliki keluarga lengkap (Sandri, 2015).
Remaja panti asuhan mempunyai kapasitas berbeda dalam menghadapi konflik yang terjadi di dalam hidupnya. Ada individu yang mampu mengatasi masalahnya dan bangkit kembali dari keterpurukan, namun ada pula yang gagal karena tidak berhasil keluar dari permasalahannya. Kemampuan untuk bertahan dan mampu menghadapi kesulitan dalam hidup bukanlah kekuatan yang datang secara tiba-tiba. melanjutkan hidup setelah ditimpa kemalangan atau bertahan di tengah lingkungan dengan tekanan bukanlah kemampuan yang datang secara otomatis. Sesuai dengan pendapat (Atighi et al., 2015) menyatakan bahwa remaja membutuhkan resiliensi psikologis karena masa remaja adalah masa yang penuh gejolak dengan berbagai macam perubahan sosial, biologis dan psikologis yang menuntut mereka agar lebih adaptif dan berpikir positif dalam menghadapi segala permasalahan yang sedang dihadapi.

Remaja yang memiliki kemampuan resiliensi biasanya mampu untuk tetap merasa tenang walaupun dalam keadaan penuh tekanan, akan cenderung mampu untuk mengendalikan emosinya, meyakini bahwa dibalik permasalahan yang melanda akan ada hikmah yang lebih baik (optimis), mampu beradaptasi secara kognitif dan bisa mengetahui akar masalah dari cobaan yang dihadapinya, memiliki rasa empati yang tinggi, memiliki keyakinan bahwa individu mampu mengatasi masalahnya melalui kemampuan, pengalaman dan keyakinan akan resiliensinya (Nikmah, 2017). Kapasitas resiliensi yang dimiliki oleh remaja yang tinggal di rumah dengan di panti asuhan juga berbeda-beda. Sesuai dengan pernyataan (Kaur \& Rani, 2012) bahwa remaja yang memiliki rumah mempunyai resiliensi psikologis tinggi dibandingkan dengan remaja yang tidak memiliki rumah. Selain itu didapatkan bahwa individu yang tinggal di dalam panti asuhan akan lebih rentan terhadap emosi negarif seperti stres, perasaan putus asa dan trauma psikologis (Syed 
Najmah Jameel et al., 2015). Individu termasuk pribadi yang resilien saat mampu menghargai diri sendiri, membutuhkan orang lain untuk berbagi ketika ia membutuhkannya dan mencari dukungan positif agar bangkit dari permasalahan (Ifdil \& Taufik, 2012). Tekanan-tekanan dan emosi negatif yang dapat membahayakan pada remaja bisa dihindari dengan memiliki kemampuan resiliensi, karena resiliensi dapat membantu individu untuk mampu bertahan serta bangkit kembali dari keterpurukan yang dialami (Dwi Rahmawati et al., 2019). Resiliensi dapat menjadi faktor protektif dari munculnya emosi negatif dan tekanantekanan sehingga individu yang memiliki kemampuan ini mempunyai potensi untuk mengurangi emosi negatif dan menjadi pribadi yang lebih kuat untuk menghadapi segala persoalan yang ada dan meningkatkan kualitas hidup. Hal ini sesuai dengan pernyataan (Dumaris \& Rahayu, 2019) bahwa remaja yang resilien memiliki kemampuan untuk menghindari sikap dan perilaku negatif hingga mereka memiliki tujuan serta kebermaknaan hidup bagi diri sendiri, keluarga dan orang lain.

Reivich, Karen dan Shatte (2002), menyatakan bahwa manfaat memiliki kemampuan resiliensi adalah untuk menangani hambatan-hambatan pada masa kecil. Hambatan tersebut misalnya berasal dari keluarga broken home, yatim piatu, kemiskinan dan tidak dipedulikan secara fisik maupun psikologis. Selain itu dengan memiliki resiliensi mampu menghasilkan manfaat lebih besar pada aspek kesejahteraan psikologis remaja yatim piatu. Dengan memiliki tingkat resiliensi tinggi, maka remaja tersebut dapat lebih mempertahankan kesehatan fisik dan kesehatan mental saat dihadapkan pada situasi yang penuh dengan tekanan (Rachmawati et al., 2019). Resiliensi mempunyai peran penting dalam mendampingi proses perkembangan remaja yang tinggal di panti asuhan (Dewi \& Henu, 2015). Dalam konteks remaja panti asuhan, mereka yang memiliki resiliensi tinggi akan mempunyai kekuatan yang berasal dari diri sendiri untuk menghadapi berbagai macam persoalan di lingkungan sosialnya serta mampu beradaptasi dengan baik. Hal ini sesuai dengan pernyataan (Murphey et al., 2013) bahwa remaja yang mempunyai resiliensi psikologis tinggi dapat bersikap proaktif menangani masalah yang ada, sehingga mampu mendorong munculnya emosi positif untuk menjalin hubungan sosial dengan baik.

Pendapat serupa juga dikemukakan oleh (Sulfahmi \& Ridha, 2017) bahwa remaja yang resilien dapat cepat pulih kembali (bounce back) setelah mengalami situasi sulit, remaja akan mengalami peningkatan kualitas dan kemampuan diri. Remaja yang resilien akan mampu beradaptasi dengan baik dari tekanan yang melanda. Sehingga resiliensi sangat penting untuk dimiliki setiap remaja dan dianggap sebagai kemampuan dasar untuk membentuk kepribadian positif dan kekuatan emosional.

\section{KESIMPULAN}

Hasil kegiatan PKM menunjukkan bahwa terdapat perbedaan hasil antara pretest dengan posttest. Hal ini dapat diartikan bahwa terjadi peningkatan resiliensi pada remaja yatim piatu dari sebelum dan sesudah diberikan pelatihan.

Melihat hal ini, membuktikan bahwa kegiatan bermanfaat dan dibutuhkan oleh remaja panti karena setiap individu mendapatkan pengetahuan baru yang mana sebelum adanya kegiatan ini remaja tidak mengetahui sama sekali makna pentingnya individu memiliki kemampuan resiliensi serta manfaat yang di dapatkan adalah remaja bisa menjadi pribadi yang lebih resilien dan mengetahui strategistrategi untuk meningkatkan resiliensi yang mudah diterapkan dalam lingkungan sosial.

\section{DAFTAR PUSTAKA}

Atighi, E., Atighi, A., \& Atighi, I. (2015). Predicting Psychological Resilience 
Based on Parenting Styles in Girl Adolescence. International Research Journal of Applied and Basic Sciences, 9(8), 13401344. www.irjabs.com

Connor, K. M., \& Davidson, J. R. T. (2003). Development of a new Resilience scale: The Connor-Davidson Resilience scale (CD-RISC). Depression and Anxiety, 18(2), 76-82. https://doi.org/10.1002/da.10113

Desmita. (2014). Psikologi Perkembangan Peserta Didik: Panduan bagi Orangtua dan Guru dalam Memahami Psikologi Anak Usia SD, $S M P$ dan SMA. PT Remaja Rosda Karya.

Dewi, G. K. \& Henu, B. (2015). Resiliensi Pada Remaja Yatim Piatu yang Tinggal di Panti Asuhan. Jurnal SPIRITS, Vol.5, No.2, Mei 2015. ISSN: 2087-7641.

Dumaris, S., \& Rahayu, A. (2019). Penerimaan diri dan resiliensi hubungannya dengan kebermaknaan hidup remaja yang tinggal di panti asuhan. Jurnal Sosial, 3(1), 71-77.

Herdiani, W. (2018). Resiliensi Psikologis. Prenadamedia Group.

Ifdil \& Taufik. (2012). Urgensi Peningkatan dan Pengembangan Resiliensi Siswa di Sumatera Barat. Pedagogi, XII(2), 115121.

Illahi. S. P. K. \& Akmal, S. Z. (2017). Hubungan Kelekatan dengan Teman Sebaya dan Kecerdasan Emosi pada Remaja yang Tinggal di Panti Asuhan. . Psikohumaniora: Jurnal Penelitian Psikologi, Vol 2, No 2 (2017), 171 - 181.: http://dx.doi.org/10.21580/pjpp.v2i2 .1854. ISSN 2502-9363 (print); ISSN 2527-7456 (online)

Kaur, S., \& Rani Asstt Professor Senior Research Fellow, C. (2012). being resilient (Werner \& Smith, 1992; Werner, 1995), strong self-concept (Markus. III(Vi), 27-47. www.ijellh.com

Murphey, D., Barry, M., \& Vaughn, B. (2013). Positive Mental Health: Resilience. Child Trends, 3(January), 1-6. http://www.childtrends.org/?publicat ions $=$ positive-mental-health-resilience Nikmah, R. (2017). Peran Guru BK Dalam Meningkatkan Resiliensi Siswa. Seminar Nasional BK FIP-UPGRIS. 230-238.

Purwanti, W., \& Aulia, L. A.-A. (2017). Perbedaan Resiliensi antara Remaja yang Hidup dalam Keluarga Lengkap, Keluarga Single Parent, dan Remaja yang Hidup di Panti Asuhan. Jurnal Psikologi, 4(2), 62-70.

Rachmawati, B. D., Listiyandini, R. A., \& Rahmatika, R. (2019). Seberapa Jauh Aku Bisa Bangkit? Sebuah Studi Mengenai Profil Resiliensi Psikologis Remaja Panti Asuhan. Insight: Jurnal Pemikiran Dan Penelitian Psikologi, 15(2), 232.

https://doi.org/10.32528/ins.v15i2.188 4

Reivich, Karen dan Shatte, A. (2002). The Resilience factor: 7 essential skill's for overcoming life's inevitable obstacles. Random House, Inc.

Rojas F., L. F. (2015). Factors Affecting Academic Resilience in Middle School Students: A Case Study. GiST Education and Learning Research Journal, 11(11), 6378.

https://doi.org/10.26817/16925777.28 6

Sandri, R. (2015). Perilaku Bullying Pada Remaja Panti Asuhan Ditinjau Dari Kelekatan Dengan Teman Sebaya Dan Harga Diri. Jurnal Psikologi Tabularasa, 10(1), 43-57.

Sulfahmi, A., \& Ridha, A. A. (2017). Resiliensi Remaja Yatim Piatu Yang Melaksanakan Salat Tahajud. Psikologika: Jurnal Pemikiran Dan Penelitian Psikologi, 22(2), 36-47. https://doi.org/10.20885/psikologika.v ol22.iss2.art4

Suseno, M. N. (2013). Efektivitas Pembentukan Karakter Spiritual Untuk Meningkatkan Optimisme Terhadap Masa Depan Anak Yatim Piatu. Jurnal Intervensi Psikologi (IIP), 5(1), 1-24. 
https://doi.org/10.20885/intervensipsi kologi.vol5.iss1.art1

Syed Najmah Jameel, Shawkat Ahmad Shah, \& Showkat Ahmad Ganaie. (2015). Perceived Social Support and Resilience among Orphans: A Systematic Review. International Journal of Indian Psychology, 3(1).

https://doi.org/10.25215/0301.155

Widiasavitri, I. A. R. T. dan P. N. (2016). Pada

Remaja Awal Di Panti Asuhan Kota Denpasar. Pendidikan, 3(3), 542-550. 